其の為右第 2 指腱鞘炎を発症した

この経験から以下の知見を得た。

(1)軽い腱鞘炎は原因を除けば自然に直る。

(2)其の腱鞘炎の自然治癒に 2 週間を要した。

(3)マウスによる愁訴を無視してはならない.

(4)マウス操作もキー操作闰様連続作業時閪管理が障害予 防上重要である。

\section{5. 給食調理場における作業危険度分類と職業性頸腕障} 害について

内藤堅志（トキワ松学園横浜美術短大） 阿部真雄, 服部由季夫（東海大学体育学部） 学校給食調理員の多くが頸肩腕障害，腱鞘炎，指曲が りを訴えて抢り，そして学働内容は食㫫の高品質化，食 品衛生, 食器の重量化などにより変容しつつあり，今後 労働負担は增加することが奬念される。今回は調理形態 の異なる 3 調理場のVTR を紹介した。内容は俱担が多 いと思われる作業の手首・腕・肩の状態，重量物取り扱 い作業姿勢の他，ヒヤリハット及び作業ミス等について 紹介した。

我々は給食調理場の快適化という視点から，給食調理 員に対して自主的改善を促進する目的で作業問題・ヒヤ リハットについて TMQ等を行ってきた。その結果伦険 要因を認識している部分に対しては対策・改善が行える ようになったが，作業問題・ヒヤリハットの多くを認識 していない事も判明した。この事から認識していない部 分を簡便的且つ客雄的に評仙古るための7 段階評価（危 険度分類）を作成した。今後も危険度分類の調査を続け, 快適化の検討を行っていきたいと考えている.

\section{平成 11 年度日本産業衛生学会 九州地方会学会}

\section{<特別講演 $>$ \\ じん肺の新しいアプローチ \\ い草作業者のじん肺について}

伊藤清隆（熊本労棪病院呼吸器内科）

\section{1-ブロモプロパン吸入曝露によるラット海馬 CA1 領 野の入出力回路}

○笛田由起子 ${ }^{1}$, 石由尾徽 ${ }^{2}$, 耑谷奎 ${ }^{2}{ }^{2}$, 保利一 ${ }^{2}$

( ${ }^{1}$ 産医大産業保健学部生体情報, ${ }^{2}$ 同環境管理) 1-ブロモプロパン（1-BP）はフロン代替品として近年

\footnotetext{
* 1999 年 6 月 11 日 (金) $14: 00 \sim 17: 00,12$ 日（土） 9：00 $\sim 15: 30$, 熊本大学医学部 学会長: 上田 厚（熊本大学: 医学部衛生学講座)
}

需要が高まっている，生殖器・末梢神経では毒性が報告 されているが，中枢神経系機能への影響は報告されてい ない。我々は，1-BPを 4 週間吸入嚗露（1500 ppm，6 時間/日，5日/週）された雄性Wistarラットの海䭴ス ライス標本を作り，神経細胞における情報処理の変化を 調べた。CA1 領野の興奮性入力線維であるSchaffer 側 枝を電気刺激し，錐体細胞層から細胞外記録した。入力 系情報処理の評価は，EPSP/Spike (E/S) curveを，出 力系はペアパルス応答を，それぞれ清浄空気を吸入した 対照群と比較した。その結果，1）1-BP群の E/S curve の立ち上がりに変化は箚かった，2）ペアパルス抑制が 曝露 1 週間目から減少（脱抑制）した。これらの結果は, 1-BP 嚗露によって，神経回路が影響を受けたことを明 示し，その変化は抑制機能の減弱，すなわち興奮系の克 進を示唆した。

\section{2. コークス炉作業者における $\mathbf{P A H}$ 曝露の生物学的モ ニタリング}

○们場正良，偯久松，弥富美奈子，榎真作史，友国勝魔 (佐賀医大地域保健) 山野優子（東京女子医大） 原 邦夫 (労研) 潘国偉（中国遼寧省） 高橋 謙 (座業医大環境疫学) 花岡知之（国立がんセンター，労研） 製鉄所コーク久炣作業者を対象に，多環芳香族炭化水 素（PAH）嚗露の生物学的モニタリング調查を行った。 コークス炉作業は職業性肺癌の発生職場として知られて いる，作業に伴う PAH曝露の生物学的影響量である内 IIII球 DNA 付加体を测定した，対象者は，コークス炬作 業者 140 名，刘照者 41 名。白血球 DNA 付加体（主に多 環持香族系）は， ${ }^{32} \mathrm{P}$ ポストラベル法（ヌクレアーゼ P1 法）で测定し，测定值は $10^{8}$ 個ヌクレオチドあたりの付 加体数で示守. 白血球 DNA 付加体濃度を比較すると, 作業者：0.40（0.28，0.70)/10 ヌクレオチド（メジアン $(25,75 \%$ 值 $))$, 詨照者：0.35 (0.25，0.53)/108ヌクレオ チド，作業者で，高い傾们があるが有意差はない。今後, 作業環境濃度，喫煙量との関係を検壦する。

\section{3. カドミウム輁露によるヒトリンパ球 MAP キナーゼ シグナル伝達系への影響}

井料住久，松岡雅人，伊規須英輝 (産医大環境中青)

カドミウムの慢性的な曝露により，リンパ球にカドミ ウム集積が生じることが報告されている。一方，in vitroに拈いて低濃度カドミウム曝露によりリンパ球で メタロチオネインや熱ショック蟲昌の誘導，アポトーシ スが起こること等が報告されている。そこで，カドミウ 